\title{
蒸気タービンロータ局所領域におけるクリープボイド成長シミュレーション† 緒 方 隆 志* Creep Void Growth Simulation of Local Area in a Steam Turbine Rotor
}

by

\author{
Takashi OGATA *
}

In order to reduce maintenance cost of high temperature components in aged thermal power plants, it is necessary to improve accuracy of remaining life assessment methods. High temperature components such as steam turbine rotors are operated under creep loading condition where creep voids initiate and grow on grain boundaries. Development of a void growth prediction method is important for reliable maintenance of these components. Purposes of this study are to clarify void growth behavior of a turbine rotor material under creep loading condition, and to develop void growth simulation program that can predict damage extension process in the components under actual operating condition quantitatively. Creep tests have been conducted on a $1 \mathrm{Cr}-\mathrm{Mo}-\mathrm{V}$ forging material and creep damaged specimens were produced by interrupting the tests. From observation of the creep damaged specimen, spherical shape voids initiate and grow up to their length of $2 \mu \mathrm{m}$ on the grain boundary at initial stage of damage, and then these voids change their shape to crack-like to grow until their length reaches around $10 \mu \mathrm{m}$. Finally, crack-like voids coalesce each other to form one micro crack along grain boundary. It can be concluded that void growth rate is controlled by diffusion and power law creep under constrained condition based on theoretical consideration of void growth mechanism. Through these discussions, a new void growth model was proposed by modifying conventional models. A void growth simulation program was developed by incorporating the void growth model into a personal computer. It was confirmed that void growth process under the creep condition in the experiment was well predicted by the simulation program. The simulation program was also applied to predict creep void growth behavior in an actual steam turbine rotor during operation.

Key words : Creep void, Cr-Mo-V forging steel, Void growth simulation, Steam Turbine Rotor

\section{1 緒言}

我が国の火力発電プラントの 8 割近くは, 累積運転時 間が 10 万時間を超える経年火力であり，20万時間を超 えるものも $30 \%$ にのぼる。最近では，20 万時間使用され たタービンロータやケーシングの廃却後の詳細な破壊検 查に打いてボイドの発生・成長が生じていることが報告 されている.1)長期使用高温機器に対するこのような微視 的損傷の成長を定量的に推定できれば，より信頼性の高 い余寿命評価が可能となる。しかしながら, 既存の余寿 命評価では，その時点の組織観察結果（ボイド発生状態） から密度，長さ等により損傷状態を定義しているが，用 いているマスターカーブが加速条件下で作成されたもの であり，実機における損傷進行状態が必ずしも的確に反 映されていない，また，その後の定量的な寿命予測を行 うことができないなどの問題点がある．解析的評価では 得られた温度・応力等の力学条件からき裂の発生寿命を 推定することによって余寿命を推定するが，これは現象 論的に導かれた寿命評価式に基づくき裂発生までの期間 の推定であり，損傷の進行過程を定量的に予測すること はできない。これに対し，多田ら ${ }^{2)}$ は，粒界の抵抗力を 減少させることによって微小き裂の発生・成長をシミュ レーションする手法を提案しており，微小き裂の成長を
定量的に予測することを可能にしている.

一方, 微小き裂発生以前のボイドの成長については, 理論的検討をべースにいくつかの力学モデルが提案され

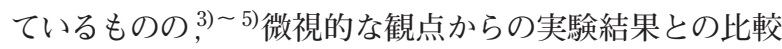
によるモデルの妥当性は検証されてこなかった。著者 ${ }^{6)}$ はボイラ材料を対象にクリープボイドの発生・成長過程 を詳細に観察し, 観察結果に基づいて既存モデルを改良 したボイド成長モデルおよび成長式を提案した。さらに， 実験における観察結果との比較により，同成長式を用い てボイド成長速度および成長過程を良好に推測できるこ とを示した。

本研究では材料の局所領域におけるボイド成長を推測 するためのシミュレーションプログラムを開発するとと もに, 蒸気タービンロータ材料のクリープ損傷過程との 比較により，その妥当性を検討する。ささに，同プログ ラムを用いてタービンロータの実機条件を想定してボイ ド成長過程を推測することを試みる.

\section{$2 \cdot 1$ 試験方法}

\section{2 クリープ損傷とボイド発生状態}

試験に用いた材料は，タービンロータカップリング部 ${ }^{1)}$ より採取したものである。化学成分扎よび機械的性質を Table 1 および 2 に示す. Fig. 1 に光学顕微鏡で観察し

$\dagger \quad$ 原稿受理 平成 18 年 5 月 9 日 Received May 9, 2006 @ 2007 The Society of Materials Science, Japan

* 正 会員 財) 電力中央研究所 干201-8511 狛江市岩戸北, Central Res. Inst. of Electric Power Industry, Iwatokita, Komae, 201-8511 
Table 1 Chemical composition of the rotor material.

\begin{tabular}{|c|c|c|c|c|c|c|c|c|}
\hline $\mathrm{C}$ & $\mathrm{Si}$ & $\mathrm{Mn}$ & $\mathrm{P}$ & $\mathrm{S}$ & $\mathrm{Ni}$ & $\mathrm{Cr}$ & $\mathrm{Mo}$ & $\mathrm{V}$ \\
\hline 0.28 & 0.34 & 0.52 & 0.018 & 0.017 & 0.37 & 1.06 & 1.10 & 0.29 \\
\hline
\end{tabular}

Table 2 Mechanical property of the rotor material.

\begin{tabular}{|c|c|c|c|}
\hline $\begin{array}{l}0.2 \% \text { Proof } \\
\text { Stress (MPa) }\end{array}$ & $\begin{array}{l}\text { Tensile } \\
\text { Strength (MPa) }\end{array}$ & $\begin{array}{c}\text { Elongation } \\
(\%)\end{array}$ & $\begin{array}{l}\text { Reduction of } \\
\text { Area (\%) }\end{array}$ \\
\hline 696.4 & 847.3 & 15.6 & 47.1 \\
\hline
\end{tabular}

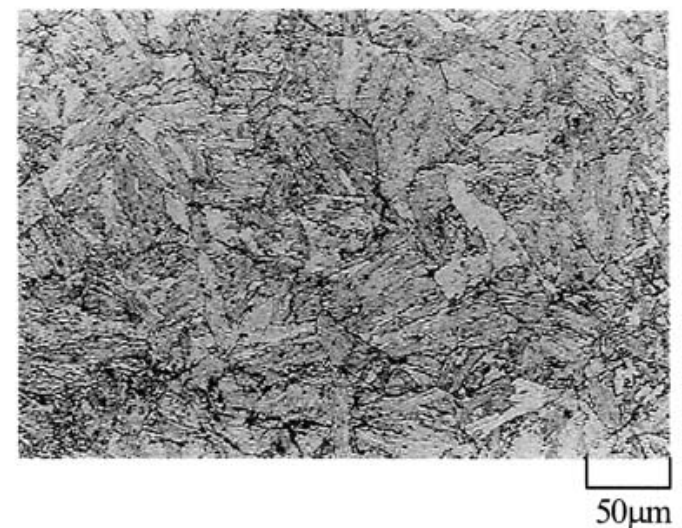

Fig. 1 Microstructure of the rotor material.

た微視組織を示す。焼き戻しべイナイト組織であり，平 均結晶粒径は $57.2 \mu \mathrm{m}$ である. Fig. 2 に示す標点間 $50 \mathrm{~mm}$ の中実丸棒単軸クリープ試験片を用いて, クリープ試験 を実施した。得られた破断試験結果を基に, 温度 $580^{\circ} \mathrm{C}$, 応力 $180 \mathrm{MPa}$ でクリープ中断試験を実施した，破断時間 に対して中断時間が $25 \%, 50 \% ， 75 \%$ となる時間で試験を 中断し，クリープ損傷材を作製した。走查型電子顕微鏡 を用いて, 約 $1 \mathrm{~mm}^{2}$ 範囲のボイド発生状態を観察した。

\section{$2 \cdot 2$ 試験結果}

クリープ試験で得られた供試材のクリープ曲線を Fig. 3 に示す。本試験条件での破断時間は 4200 時間であった。 クリープ損傷中断材の試験片軸方向縦断面において観察 された代表的なクリープボイドおよび微小き裂を Fig. 4 に示す。

$25 \%$ 損傷材では, 粒界上に多数の球状ボイドが観察さ れ，最大長さで $3 \mu \mathrm{m}$ 程度であった，50\% 損傷材では，球 状ボイドとき裂状ボイドが観察され，25\% 損傷材に比べ るとボイド個数はやや増加して打り,き裂状ボイドの最 大長さは $6 \mu \mathrm{m}$ 程度であった。 $75 \%$ 損傷材では擬球状およ

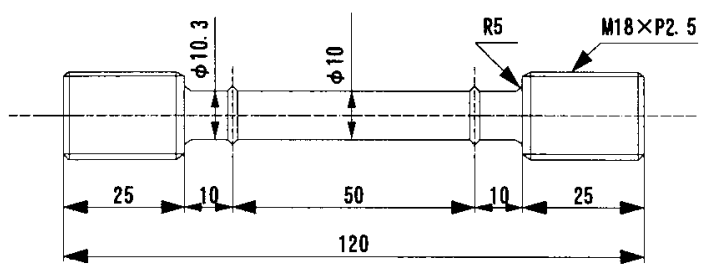

Fig. 2 Creep test specimen geometry.

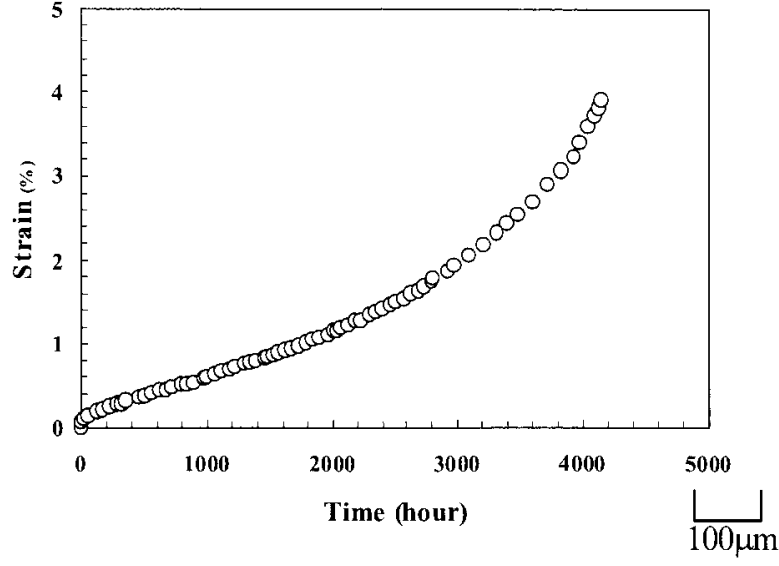

Fig. 3 Creep deformation curve.

びき裂状ボイドに加え，これらが連結して粒界上に成長 したき裂状ボイドが観察された。ボイド個数は $50 \%$ 損傷 材とそれほど変らないが，最大長さは $9 \mu \mathrm{m}$ 程度であっ た。き裂状ボイドは観察されたが，1結晶粒長さまで成 長した微小き裂は観察されなかった。また， $75 \%$ 損傷中 断材の伸び打よび絞りは $3 \%$ 程度であり，巨視的には顕 著なクリープ変形を生じていなかった。 $100 \%$ 損傷材（破 断材）では，破断部から離れた平行部を観察したが，他 の損傷材に比べ $4 \mu \mathrm{m}$ を超えるき裂状ボイドおよびそれら が 1 結晶粒長に成長した微小き裂も観察された。観察さ れた多くのボイドは，1結晶粒界上に単独で発生・成長 していた。また，発生していたボイド個数は，2次元的 な表面観察に打いて, 応力軸に垂直に近い粒界が相対的 に多く, 応力軸からの角度が大きくなるにつれて相対的 に減少するものの，応力軸に直角に近い粒界でもボイド の発生が認められた。これは, ボイドの発生には粒界の 3 次元構造や性状が関与することを示唆するものである. 既に 304 ステンレス鋼を用いて実施したクリープおよび ひずみ制御クリープ疲労試験に打けるボイド発生状況の 観察結果打よび後方散乱パターン解析に基づくボイド発 生に及ぼす結晶粒方位の影響を調査した結果からも同様 な示唆が得られている.?

\section{3 ボイド成長シミュレーションプログラムの開発}

\section{$3 \cdot 1$ 結晶粒作成プログラム}

タービンロータ材の結晶粒をコンピュータによりシミュ レーションする手法として，核生成一成長モデルを用い

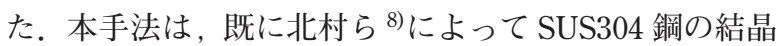
粒作成に適用されている。核生成一成長モデルにより， 表面（平面）粒界と深さ方向に任意の界面角度を有する 結晶粒作成の概要を以下に示す。

I 任意の領域内に結晶核をランダムに配置する.

II それぞれの結晶核に対してランダムな核生成時間を 確率変数として与える。

III それぞれの結晶核は，核生成を終了した後に等方的 に一定速度で成長するものとする。

IV 結晶作成領域を小領域（格子）に分割し，最小時間 で小領域中心に到達した核が小領域を占有る。 


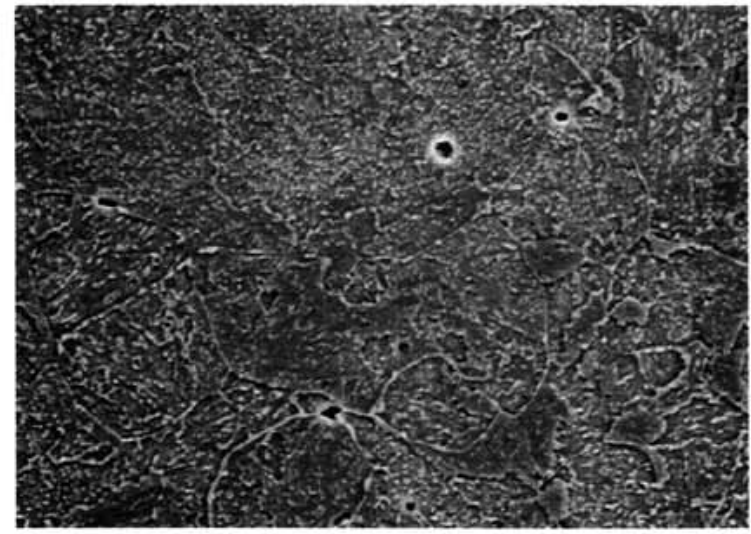

a) Time $=1050$ hour ( $25 \%$ damage)

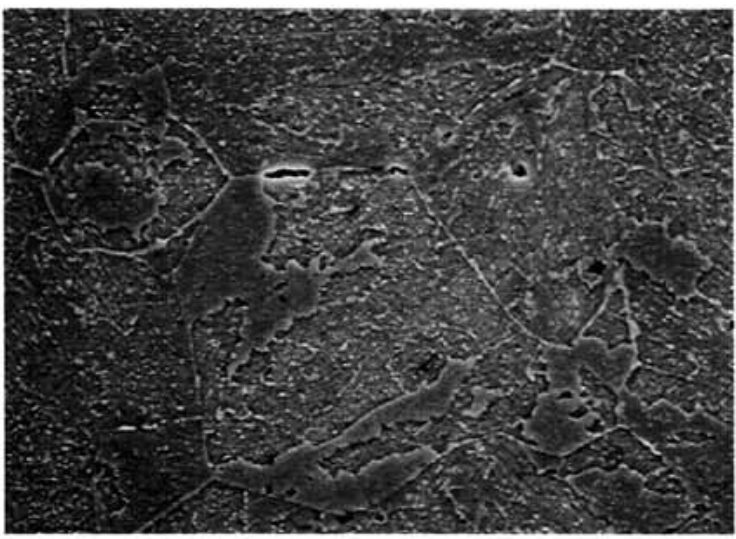

b) Time $=\mathbf{2 1 0 0}$ hour (50\% damage)

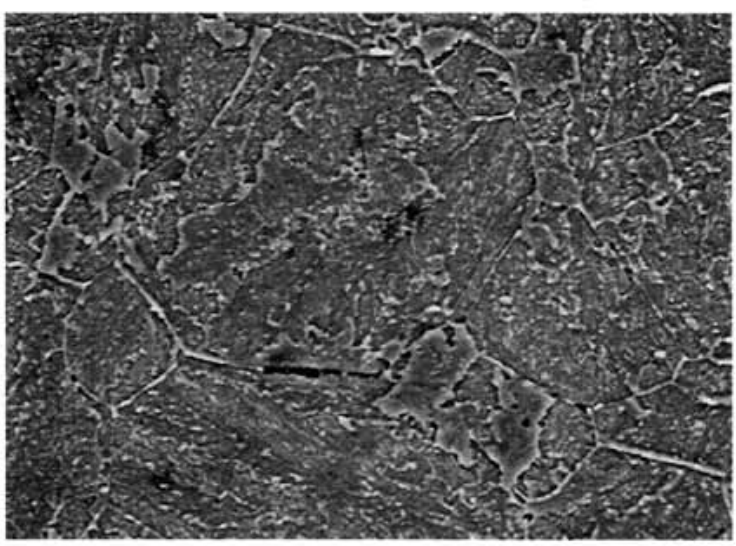

c) Time $=\mathbf{3 1 5 0}$ hour (75\% damage)

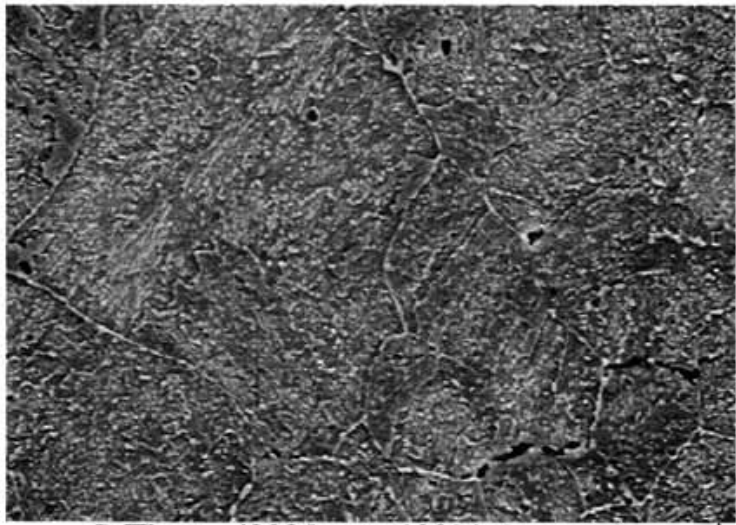

d) Time $=\mathbf{4 2 0 0}$ hour ( $100 \%$ damage)

$10 \mu \mathrm{m}$

Fig. 4 Creep void observation in interrupted creep test specimens.
V それぞれの結晶核成長（小領域占有）過程において 他の結晶生成相に出会うとその方向への成長を停止 し，結晶粒界を形成する。

VI それぞれの結晶粒界は深さ方向にランダムな角度を 有するものとする.

粒界の作成にあたっては，x，y 方向長さ，格子数，結 晶核数, 結晶生成に打ける最大待与時間, 核成長速度, 結晶核間最小距離を任意に入力する。結晶粒の作成にお ける入力パラメータの生成結晶粒に及ぼす影響は，概ね 以下のような傾向となる。

“格子数” は，その増減によって結晶粒や 3 重点の数 はほとんど変わらないが，実際の粒界に近くするには “格子数”は多いほうがよい。“結晶核数”は，少ないほ ど結晶粒が大きくなり，結晶粒サイズの標準偏差が大き くなる傾向を示すので，作成したい結晶粒径に応じて適 切に選定する。計算時間は “結晶核数”に比例して増大 する。核生成が開始するまでの最大の時間を指定する “最大成長開始待ち時間” は，小さくするほど平均粒径 が大きくなり， 3 重点が少なくなる傾向はあるものの，そ れほど顕著ではなく，ある值以上ではほとんど変化しな くなる。結晶核の “成長速度” は，大きいほど平均粒径 が大きくなり， 3 重点が少なくなる傾向を示すものの， あ る值以下ではほとんど変化しなくなる。“結晶核最小跑 離”は，結晶核間の最小距離を定めるものであり，大き いほど結晶粒径が大きくなり, 結晶粒と 3 重点の数が減 少する.

第 2 章で述べた供試タービンロータ材料の結晶粒を模 擬するために試行計算を行った後，各パラメータを決定 し，作成されたタービンロータ材模擬結晶粒を Fig. 5 に 示す．結晶粒は， $\mathrm{x}$ および $\mathrm{y}$ 方向長さ $1.0 \mathrm{~mm}$, 即ち面積 $1 \mathrm{~mm}^{2}$ で作成し，平均結晶粒径は $54 \mu \mathrm{m}$ である。このよ うに，本粒界作成プログラムにより，Fig. 3 に示した供 試材と同等の組織を模擬できていることがわかる.

$3 \cdot 2$ ボイド成長シミュレーションプログラム

上述した粒界作成プログラムによりコンピュータ上に 作成した粒界を用いてボイド成長をシミュレーションす るプログラムを開発した。高温で一定応力負荷を受ける，

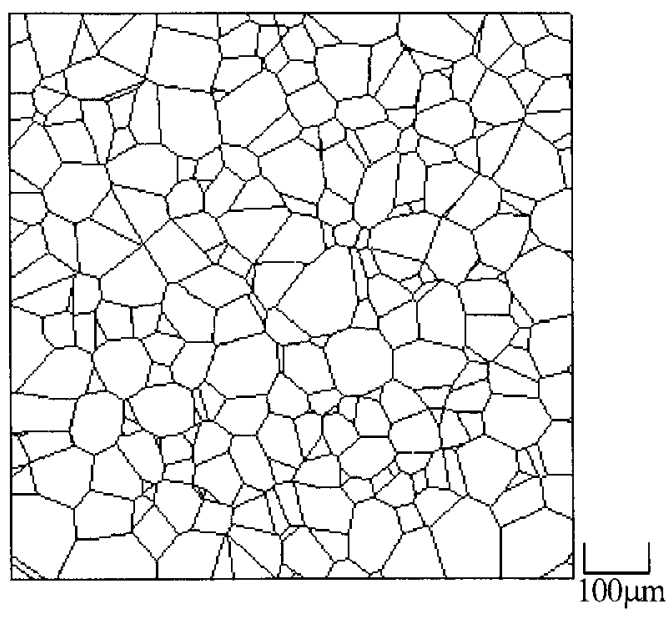

Fig. 5 Simulated microstructure of the rotor material. 
即ちクリープ条件下の材料におけるボイド成長シミュレー ションフローを Fig. 6 に示す.

まず，作成されたすべての粒界上にボイドの発生源を 任意の個数等間隔で配置する. 負荷応力は, $\mathrm{X}$ および $\mathrm{Y}$ 方向に $\sigma_{\mathrm{x}}$ および $\sigma_{\mathrm{y}}$ として 2 次元で設定することができ， それにより各粒界に作用する垂直応力， $\sigma_{\mathrm{n}}$ は，深さ方向 の粒界角度を考慮した次式で表されるとした。

$$
\sigma_{\mathrm{n}}=\left(\sigma_{\mathrm{x}} \sin ^{2} \theta\right)+\sigma_{\mathrm{y}} \cos ^{2} \theta \sin ^{2} \alpha
$$

ここで， $\theta$ は表面粒界の $\mathrm{y}$ 軸に対する角度， $\alpha$ は $\mathrm{y}$ 軸に 対する深さ方向の角度である. 各粒界に $\sigma_{\mathrm{n}}$ が作用する 時のボイドの成長式は, 著者 ${ }^{6}$ が既に提案しているボイ ド成長モデルから導出された式を用いる，同モデルは， ボイド成長に対し拡散およびまわりの結晶粒のクリープ 変形による複合成長機構とまわりの粒からの拘束効果を 考慮したものであり，同モデルにより導かれた成長式に よってクリープ扎よびクリープ疲労条件下のボイド成長 が良好に推定できることを確認している。ボイド形状が 擬球状およびき裂状の場合のボイド成長式はそれぞれ次 式で表される。

(擬球状ボイド)

$$
\frac{d a}{d t}=\frac{a \dot{\varepsilon} c}{2 h(\psi)}\left(\frac{\Lambda}{a}\right)^{3} \frac{1}{L+M}
$$

（き裂状ボイド）

$$
\begin{aligned}
& \frac{d a}{d t}=\frac{\alpha a \dot{\varepsilon} c}{4 \pi h(\psi)}\left(\frac{\Lambda}{a}\right)^{5 / 2} \frac{1}{(L+M)^{2 / 3}} \\
& \Lambda=\left(\frac{\delta_{\mathrm{b}} D_{\mathrm{b}} \Omega \sigma_{\mathrm{n}}}{k T \dot{\varepsilon}_{\mathrm{c}}}\right)^{1 / 3}
\end{aligned}
$$

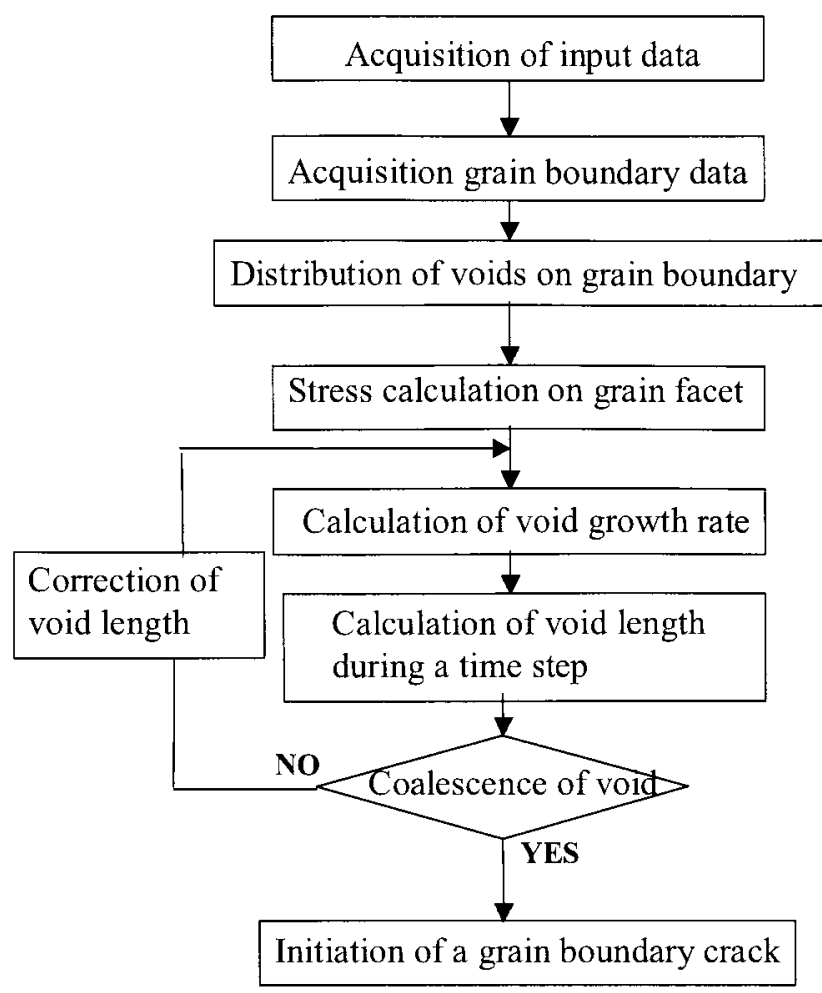

Fig. 6 Void growth simulation flow. $h(\psi)=\frac{1}{1+\cos \psi-(\cos \psi) / 2} \frac{1}{\sin \psi}$

$M=\ln \left(\frac{a+\Lambda}{a}-\left(3-\left(\frac{a}{a+\Lambda}\right)^{2}\right)\left(1-\left(\frac{a}{a+\Lambda}\right)^{2}\right) / 4\right)$

$L=\frac{2 b}{\beta}\left(\frac{\Lambda}{a+\Lambda}\right)$

$\alpha=\left(\frac{4 \pi h(\psi)}{(4 \sin (\psi / 2))^{3 / 2}}\right)\left(\frac{\delta_{\mathrm{b}} D_{\mathrm{b}} \sigma \Lambda}{\delta_{\mathrm{b}} D_{\mathrm{s}} \gamma_{\mathrm{s}}}\right)$

ここで, $a$ : ボイド半径, $\psi$ : ボイド先端角度, $\dot{\varepsilon}_{\mathrm{c}}$ : 定常 クリープひずみ速度, $\delta_{\mathrm{b}}$ : 粒界幅, $D_{\mathrm{b}}$ : 粒界拡散係数, $\Omega$ : 原子容, $\sigma_{\mathrm{n}}$ : 粒界垂直方向応力, $k$ : ボルツマン定 数, $T:$ 絶対温度, $b$ : ボイド間距離, $\beta$ : クリープ指数 $n$ に依存する定数, $d$ : 結晶粒径, $D_{\mathrm{s}}$ : 表面拡散係数, $\gamma_{\mathrm{s}}$ : ボイド表面張力である。ボイド半径のみが逐次計算 に打いて変化する。ボイドは粒界上に均等に配置し，初 期直径は任意に設定することができる。ボイドは，式 (2) および式 (3)の速い方の速度で成長することとする（粒 界上のボイドは粒界 3 重点または隣接するボイドと合体 するまで成長する)，ボイドが成長して隣接するボイドと 合体した場合には，1粒界長さの微小き裂の発生となる。

一般的には，個々の粒界性状，ボイド発生，成長は確 率統計的要素を含むものであるが，本研究では簡単のた めボイド核はすべての粒界に存在するとし，それらの成 長も力学的条件にのみ依存し, 上述したボイド成長則に 従うとして取り扱った。また，本成長則が成立する応力 範囲については㛜密な議論がなされていないが，ここで は粒界に作用する応力 $\sigma_{\mathrm{n}}$ が $40 \mathrm{MPa}$ 以上の粒界における ボイド成長のみをシミュレーションした。

\section{4 クリープボイド成長シミュレーション}

\section{$4 \cdot 1$ 試験条件に対するシミュレーション}

第 2 章で実験結果を示した温度 $580^{\circ} \mathrm{C}$ ，応力 $180 \mathrm{MPa}$ の条件下で, ボイド初期寸法を $0.1 \mu \mathrm{m}, 1$ 粒界上のボイ ド個数を 1 個として, ボイド成長シミュレーションを行 い，その中で最大ボイドの成長過程と各損傷中断材の最 大ボイドを比較したものを Fig. 7 に示す. 本シミュレー ションに用いた物性值を Table 3 に示す. 応力とクリープ 変形速度の関係はロータ材を対象にこれまで実施したク リープ試験結果に基づいて次式で与えた。

また，粒界および表面拡散係数は，Frost ら ${ }^{99}$ の文献に おける温度依存性を示すデータの平均值とした。ただし， 複数の研究による実験結果にばらつきが大きいことから， ここでは, 粒界および表面拡散にばらつきの影響を調べ るため, これらの平均值に対し 10 倍および $1 / 10$ 倍の值 を用いて計算した結果を併せて示している。ボイド成長

Table 3 Physical values used in the simulation.

\begin{tabular}{|ccc|cc|}
\hline$\Psi$ & 78.46 & $(\mathrm{deg})$ & $\beta$ & 0.9 \\
\hline$\gamma_{\mathrm{s}}$ & 1.95 & $\left(\mathrm{~J} / \mathrm{m}^{2}\right)$ & $\mathrm{n}$ & 3.98 \\
\hline$\delta \mathrm{bDb}$ & $5.43 \times 10^{-23}$ & $\left(\mathrm{~m}^{3} / \mathrm{s}\right)$ & $\delta \mathrm{sDs}$ & $1.59 \times 10^{-22}\left(\mathrm{~m}^{3} / \mathrm{s}\right)$ \\
\hline
\end{tabular}




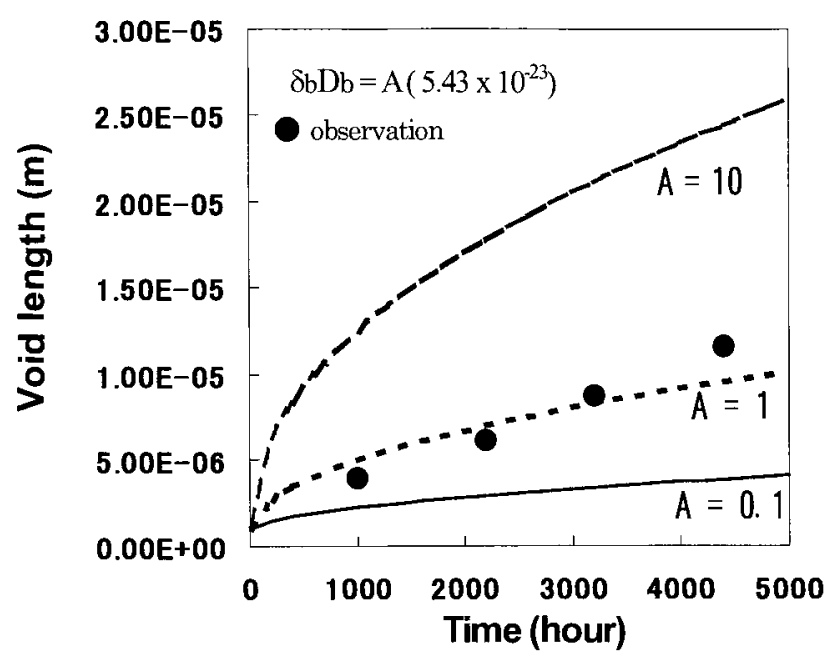

Fig. 7 Comparison of void growth simulation result between different diffusion coefficients.

挙動には拡散係数の影響が明確に認められ，拡散係数が 大きいほうがボイド成長速度も速くなる。中断試験片で 観察された最大ボイドとシミュレーション結果の比較か ら, 粒界および表面拡散係数としては平均值を用いるこ とで $\mathrm{Cr}-\mathrm{Mo}-\mathrm{V}$ 鋼のクリープ条件下のボイド成長挙動を概 ねシミュレーションできることがわかる。

次に, シミュレーションによって得られた 1050 時間後 および 3150 時間後の面積 $1 \mathrm{~mm}^{2}$ の中での局所領域を拡 大してボイド成長状態をみたものを Fig. 8 に示す。罒中 ボイドは粒界上の直線で示している。1050 時間経過後の 最大ボイド長さは $2 \mu \mathrm{m}$ 程度である。困からわかるように 時間の経過によってボイド寸法が増大していることがわ かる. Fig. 4 に示したクリープ中断試験片のボイドの状 態と比較すると，シミュレーションと観察結果では，個数 自体は異なるものの，ボイド寸法は同等であり，クリープ 試験過程のボイド成長挙動を良好にシミュレーションで きている。

\section{$4 \cdot 2$ 実機条件下のボイド成長挙動の推定}

中圧タービンロータ (容量：375MW, 主蒸気温度： $538^{\circ} \mathrm{C}$, 主蒸気圧力 : $24 \mathrm{MPa}$ ) の温度, 応力を解析した
結果からは, 第一段中心孔において温度, 応力が最も高 くクリープ損傷という観点からは最も厳しいことが明らか になっている.1)これまでに解析した数体のタービンロータ では，運転条件，ロータ形状等によって温度, 応力は異な るものの，高圧ロータでは，定常運転時の温度が 520 $530^{\circ} \mathrm{C}$, 応力が $60 \sim 80 \mathrm{MPa}$ 程度であり, 中圧ロータで は温度は同等で，応力が $80 \sim 100 \mathrm{MPa}$ 程度であるとの 結果が得られている。ここでは，代表例として㛜しい温 度，応力条件を仮定してタービンロータ中心孔の温度が $530^{\circ} \mathrm{C}$, 応力が $100 \mathrm{MPa}$ の条件下でのボイド成長シミュ レーションを実施する。シミュレーションでは，運用に おいて既に寸法 $0.1 \mu \mathrm{m}$ のボイドが発生している，即ち初 期の状態から損傷がある程度進行していると仮定した。 Fig. 9 に 5 万時間扎よび 30 万時間経過後のボイド成長 シミュレーション結果を示す。なお，本シミュレーショ ンでは，すべての粒界に初期ボイドを配置したが，罒中 には， $1 \mu \mathrm{m}$ 以上のボイドを表示している。緑線が粒界， 粒界上の黒い点または線がボイド，赤線が粒界き裂を示 している。 50000 時間経過後に $1 \mu \mathrm{m}$ を超えるボイドが 既に多数観察される。経過時間の増大とともにボイドが 徐々に成長し， 10 万時間経過後には数 $\mu \mathrm{m}$ に達していた。 30 万時間経過後には，10 $\mu \mathrm{m}$ を超えるボイドに成長して いるものもあり，5万時間に比べボイドの明確な成長が 認められる。今後は，実機タービンロータの定期検査に おけるボイド観察結果とシミュレーションとの比較検討 など，実機適用性の検証を進めたい.

\section{5 結訔}

タービンロータ材を対象にクリープ損傷材を作製し， 損傷過程におけるボイド発生状態を観察するとともに， クリープ条件下のボイド成長挙動をシミュレーションで きるプログラムを開発し，観察結果との比較により，そ の妥当性を検討した。本研究で得られた主な結果を以下 に要約する.

(1) 直径 $1 \mu \mathrm{m}$ 程度の擬球状ボイドが，破断時間の $25 \%$ で既に発生して打り，50\%，75\% 中断材では粒界に沿った き裂状ボイドが観察された。

（2）任意の結晶組織を模擬することができる粒界作成

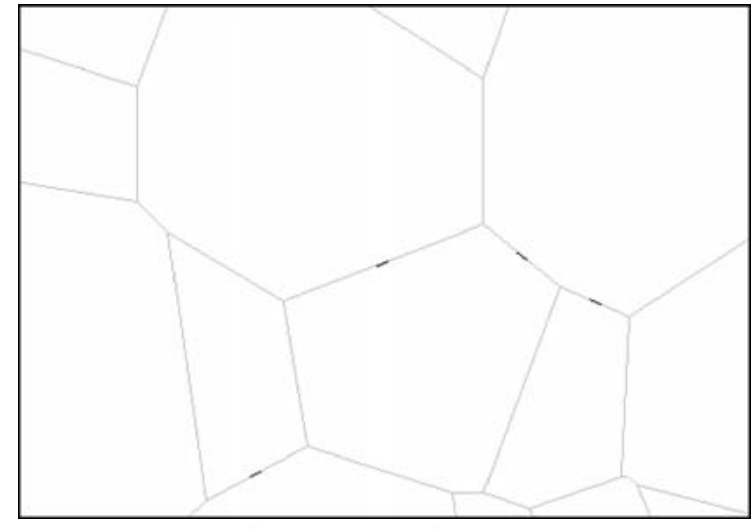

Time $=1050$ hour

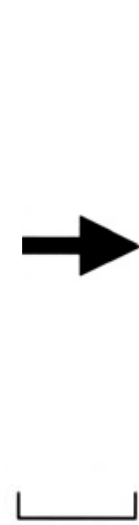

$20 \mu \mathrm{m}$

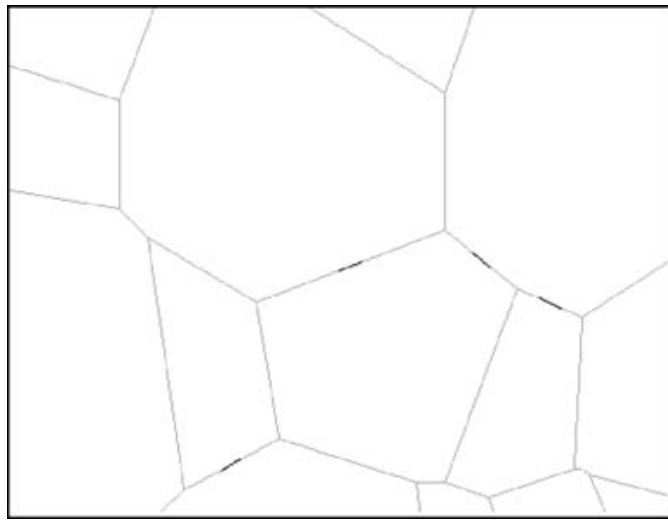

Time $=3150$ hour

Fig. 8 Void growth simulation results under the creep testing condition. 


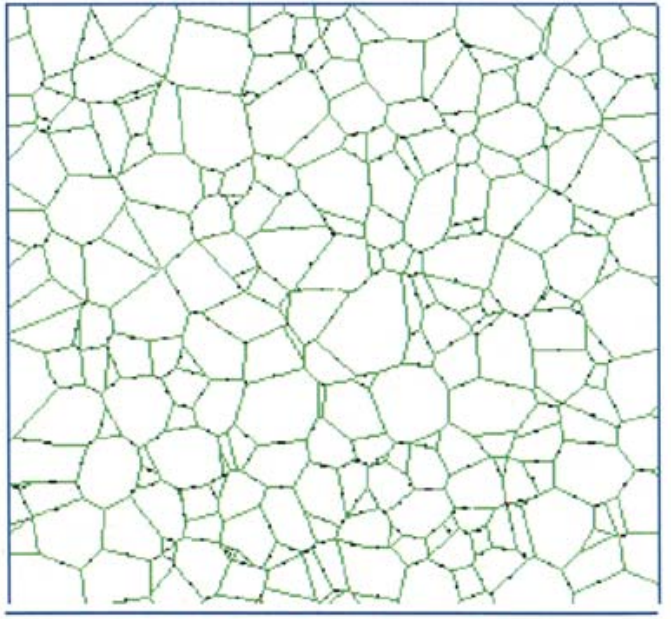

Time $=50,000$ hour

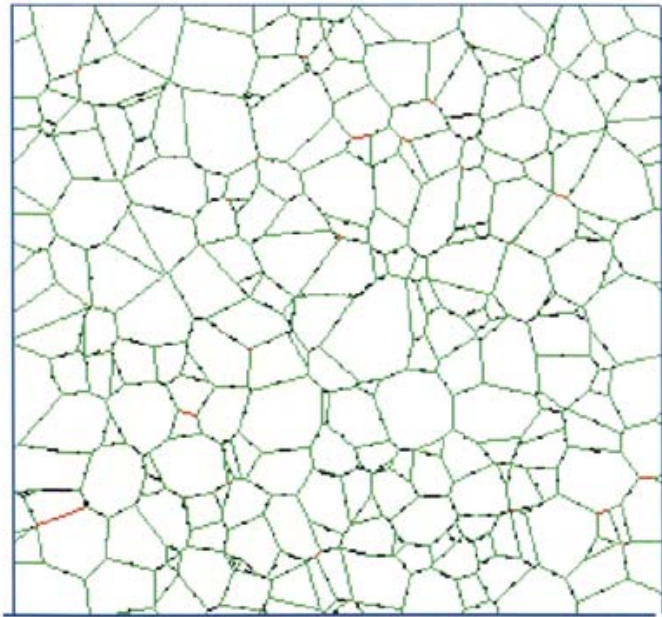

Time $=300,000$ hour

Fig. 9 Void growth simulation results of an actual turbine rotor assuming base load operation.

プログラムにより，タービンロータ材の組織と同等の組 織を模擬できることを示した。また，模擬組織を用いて ボイド成長をシミュレーションするプログラムを開発し た。同プログラムにより，クリープ条件下のボイド成長 挙動を概ねシミュレーションすることができた。

（3）実機タービンロータの使用条件を仮定して，30 万時間までのボイド成長シミュレーションを実施した。 初期ボイドを $0.1 \mu \mathrm{m}$ とした場合, 最も使用条件の綮しい 中心孔部において， 5 万時間後に $1 \mu \mathrm{m}$ 程度， 30 万時間 後に $10 \mu \mathrm{m}$ 程度に成長することが推定された。

\section{参 考 文 献}

1) K. Imamura, T. Ogata and M. Yamamoto, "Evaluation of high temperature strength property long-term service exposed turbine rotor", Proc. Int. Conf. on "Advanced in Life Assessment and Optimization of Fossil Power Plants", by EPRI, Florida (2002).

2 ) N. Tada, T. Kitamura and R. Ohtani, "Monte Carlo simulation of creep-fatigue small cracks based on a three-dimensional model of random fracture resistance of grain boundaries", Transactions of the Japan Society Mechanical Engineering Vol.56, No.524, pp.28-34(1990).

3 ) D. Hull and D. E. Rimmer., "The growth of grain-boundary voids under stress”, Phil. Mag., Vol.4, pp.673-687 (1959).
4) I. W. Chen and A. S. Argon, "Diffusive growth of grainboundary cavities”, Acta Metallugica, Vol.29, pp.1759-1768 (1981).

5 ) J. R. Rice, "Constraints on the diffusive cavitation of isolated grain boundary facets in creeping polycrystals”, Acta Metallugica, Vol.29, pp.675-688 (1981).

6 ) T. Ogata, "Cavity growth simulation of $2.25 \mathrm{Cr}-1 \mathrm{Mo}$ steel under creep-fatigue loading”, Proc. Int. Conf. on PVP2005, paper No.PVP2005-71040 (2005).

7 ) A. Nomoto and T. Ogata, "Relationship between cavity nucleation and misorientation in a crystal grain of high temperature structural materials", Denchuken houkoku T99071 (1999).

$8)$ T. Kitamura, N. Tada, Y. Kuriyama and R. Ohtani, "Distribution of grain-boundary length and inclination of Type 304 stainless steel and its effects on small crack initiation and growth under creep-fatigue conditions", Transactions of the Japan Society Mechanical Engineering, Vol.56, No.524, pp.22-27 (1990).

9 ) H. J. Frost and M. F. Ashby, "Deformation-mechanism maps for pure iron, two austenetic stainless steels and a low-alloy ferritic steel", in "Fundamental Aspects of Structural Alloy Design” edited by Jaffer R. I. and Wilcox, B. A., Pelnume, New York, pp.27-65 (1977). 